\title{
Characterization of Biosurfactant Produced by Probiotic Bacteria Isolated from Human Breast Milk
}

\author{
Laya Tabrizi Rayeni ${ }^{1}$, Shahla Soltani Nezhad ${ }^{2 *}$ \\ ${ }^{1}$ Department of Microbiology, Faculty of Sciences, Kerman Branch, Islamic Azad University, Kerman, Iran \\ ${ }^{2}$ Department of Microbiology, Jiroft Branch, Islamic Azad University, Jiroft, Iran
}

\author{
*Correspondence to \\ Shahla Soltani Nezhad, \\ Department of Microbiology, Jiroft \\ Branch, Islamic Azad University, \\ Jiroft, Iran. \\ Tel: +989133471859 \\ Email: Soltanibiotech@gmail.com
}

Received August 7, 2017

Accepted December 23, 2017

Published online March 31, 2018

\begin{abstract}
Introduction: Breast milk is an important nutrient source for rapidly growing neonates since breastfeeding protects newborns against a variety of diseases. This effect may be due to the useful and natural microflora of breast milk. Biosurfactants are unique amphipathic compounds produced by some microorganisms. The present study demonstrates the isolation and characterization of biosurfactant generating bacteria from human breast milk samples.

Methods: The human breast milk samples were collected aseptically and then cultured in MRS agar media. The biosurfactant producing ability of the isolated strains was investigated by hemolytic assay, oil spreading method, drop collapse test and emulsification index assay. The screened isolates were identified by $16 \mathrm{~S}$ rRNA gene sequencing. In vitro antibacterial activities of biosurfactants against a number of common bacterial strains were investigated by the agar disc diffusion method. This biosurfactant was characterized by Fourier-transform infrared spectroscopy (FTIR).

Results: In this study, 337 different colonies were isolated from 42 breast milk samples. The best isolates were identified as Pediococcus pentosaceus HM-1, P. pentosaceus HM-2 and $P$. pentosaceus HM-3 based on microscopic and $16 \mathrm{~S}$ rRNA gene sequencing analysis. The biosurfactant extracted from screened strains exhibited a broad spectrum of antagonistic activity against some pathogenic bacteria.

Conclusion: Bacterial strains isolated here can be valuable sources for novel biosurfactants. The Human breast milk is a safe source for obtaining biosurfactant producing probiotic bacteria and for improving gut microflora of infants.

Keywords: Human breast milk, Biosurfactant, Probiotic, Pediococcus, FTIR
\end{abstract}

\section{Introduction}

Human breast milk is the best food for infants because it fulfills all the nutritional requirements for them, additionally; it educates the infant immunity functions and confers a certain degree of protection against infectious diseases. ${ }^{1} \quad$ These effects seem a result of the action of many bioactive molecules, present in breast milk, including different antimicrobial compounds, immunoglobulins, and immune cells. ${ }^{2,3}$ The breast milk contains prebiotic substances that preserve the beneficiary bacteria in the infant gut. ${ }^{3,4}$ Human breast milk is constituted from several bacterial species, such as Staphylococci, Streptococci, Micrococci, Lactobacilli, Enterococci, Lactococci and
Bifidobacteria. ${ }^{5,6}$

Biosurfactants are heterogeneous amphipathic surface active molecules that belong to a wide range of chemical classes. These are mostly excreted by microorganisms outside the cells, and in some cases attached to the cells. ${ }^{7}$ Microbial biosurfactants produced by a wide variety of microorganisms, have a lower toxicity and a higher biodegradability than chemical surfactants. They are also effective at extreme conditions regarding temperatures, $\mathrm{pH}$ and saline concentration. Microbial surfactants play an important role in a wide variety of industrial and biotechnological applications such as agriculture, foodprocessing, cosmetics and medical fields as antibacterial, antifungal and antiviral

(C) 2018 The Author(s); Published by Zabol University of Medical Sciences. This is an open-access article distributed under the terms of the Creative Commons Attribution License (http://creativecommons.org/licenses/by/4.0), which permits unrestricted use, distribution, and reproduction in any medium, provided the original work is properly cited. 
agents. $^{7-10}$ This paper describes the separation and characterization of biosurfactant generating probiotics bacteria from human breast milk.

\section{Methods}

Sample Collection

Human breast milk samples were obtained from 42 healthy mothers in Kerman province of Iran. The samples were collected in an aseptic condition and stored on ice until delivery to the laboratory.

\section{Isolation of Probiotics Bacteria}

Direct isolation of the microorganisms was carried out using serial dilution (up to $10^{-7}$ ) of breast milk samples in $0.85 \%$ sterile saline. Serial dilutions were plated onto Man Rogosa Sharp (MRS; Biolife. Italia)) agar using the spreading method. The cultures were incubated anaerobically at $35^{\circ} \mathrm{C}$ for 5-7 days. Morphologically distinct colonies were isolated and purified by replicating on the MRS agar medium to obtain pure cultures.

\section{Preliminary Characterization of Biosurfactant Producing Bacteria \\ Hemolytic Activity}

The bacteria were screened on blood agar (Merck, Germany) plates containing $5 \%(\mathrm{v} / \mathrm{v})$ sheep blood and incubated at $35^{\circ} \mathrm{C}$ for $72 \mathrm{~h}$. Hemolytic activity was detected as the presence of a clear zone surrounding the bacterial colonies. ${ }^{9,11-13}$

\section{Oil Spreading Method}

Pure isolates were cultured in MRS broth at $35^{\circ} \mathrm{C}$ and $200 \mathrm{rpm}$ for 7 days. The broth cultures were centrifuged at $20000 \mathrm{rpm}$ for 45 minutes. ${ }^{11,14}$ The supernatant was subsequently subjected to the screening methods using oil spreading and oil collapse methods as below. Distilled water $(25 \mathrm{~mL})$ was added followed by addition of crude oil $(100 \mu \mathrm{L})$. Then, the cell-free culture broth $(20 \mu \mathrm{L})$ was dropped on to the crude oil surface. The diameter of the clear zone on the oil surface calculated and compared with those of negative control (only $20 \mu \mathrm{L}$ of distilled water). ${ }^{9,11-13}$

\section{Oil Collapse Method}

Ten microliters of the crude oil were poured into the Petri dishes. After that, $10 \mu \mathrm{L}$ of cell-free culture broth was added and the picture of the drop on the oil surface was inspected after 1 minute. Biosurfactant production was considered positive when the cultures giving flat drops. Those isolates that gave rounded drops were scored as negative, indicative of the lack of biosurfactant production. $^{11}$

Complementary Screening of Biosurfactant Producing Bacteria

Bacterial isolates positive for at least one primary screening methods were subjected to the complementary assays to verify their ability to produce biosurfactant.

\section{Emulsification Capacity (E24)}

The emulsifying capacity of isolated strains was evaluated by an emulsification index (E24). Six milliliters of crude oil and $4 \mathrm{~mL}$ of culture supernatant were combined. This mixture was vortexed at high speed for 2 minutes and allowed to stand for 24 hours. The E24 index was calculated as the ratio of the height of emulsified layer (cm) divided respectively to the total height of the liquid column $(\mathrm{cm})$. The results were compared with distilled water as negative control. ${ }^{15,16}$

\section{Identification of Bacterial Isolates \\ Phenotypic Characterization}

Different phenotypic characteristics were evaluated, as outlined in Bergey's manual of determinative bacteriology, such as motility, Gram reaction, oxidase and catalase. ${ }^{17}$

\section{PCR Amplification of Bacterial 16S rRNA Genes}

Genomic DNA was extracted from a pure culture of three isolated bacteria using DNA extraction kit (Cinnagen Cat No: DN8115C), according to the manufacturer's instructions. These isolates showed the highest biosurfactant production and were isolated from three independent samples obtained from the separate individual. The purity of the extracted DNA was checked by recording the absorbance in $260 \mathrm{~nm}$ and $280 \mathrm{~nm}$. The 2 universal oligonucleotide primers used to amplify the $16 \mathrm{~S}$ rRNA samples were as follows: forward primer $27 \mathrm{~F}$ (5'-AGAGTTTGATCCTGGCTCAG-3') and reverse primer 1492R (5'-CGGTTACCTTGTTACGACTT-3'). Polymerase chain reaction (PCR) amplification was performed in a total volume of $50 \mu \mathrm{L}$ mixture, containing $4 \mu \mathrm{L}$ templates DNA ( $50 \mathrm{ng}), 5 \mu \mathrm{L}$ of F primer ( $10 \mathrm{pmol}$ ), $5 \mu \mathrm{L}$ of R primer (10 pmol), $1 \mu \mathrm{L}$ of $10 \mathrm{mM} 4 \mathrm{dNTP}$ mix, $1.5 \mu \mathrm{L}$ of $50 \mathrm{mM} \mathrm{MgCl}_{2}, 5 \mu \mathrm{L}$ of $10 \mathrm{X}$ PCR buffer, $0.5 \mu \mathrm{L}$ of

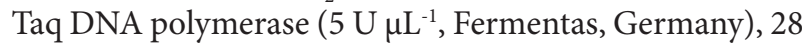
$\mu \mathrm{L}$ of sterile distilled water and microcentrifuged briefly. An initial denaturing step of $94^{\circ} \mathrm{C}$ for 3 minutes was followed by 25 cycles of amplification ( 1 minute $94^{\circ} \mathrm{C}, 1$ minute $56^{\circ} \mathrm{C}, 1.5$ minutes $72^{\circ} \mathrm{C}$ ) and a final extension step at $72^{\circ} \mathrm{C}$ for 5 minutes. PCR products were separated by electrophoresis of $5 \mu \mathrm{L}$ of PCR product in a $1 \%$ agarose gel for 2 hours and by staining with ethidium bromide. Amplification products were stored at $-20^{\circ} \mathrm{C}$. The clean PCR product was subjected to cycle sequencing in both directions.

\section{Phylogenetic Analysis}

Phylogenetic analysis was carried out as follows: the sequences were checked using Bioedit V.5.0.9.18 A BLAST was carried out at http://blast.ncbi.nlm.nih.gov/ Blast.cgi to identify the nearest neighbors. ${ }^{19}$ Alignment, phylogenetic and molecular evolutionary analyses were 
conducted using MEGA version $5 .^{20} \mathrm{~A}$ bootstrap test and reconstruction were done based on 1000 replications to confirm the validity of the phylogenetic tree. ${ }^{21}$ The nucleotide sequences of $16 \mathrm{~S}$ rRNA gene of bacterial strains (Pediococcus pentosaceus HM-1, P. pentosaceus HM-2, and $P$. pentosaceus HM-3) reported in this study have been deposited in GenBank under Accession No: KU527555, KU527556 and KU527557, respectively.

Characterization of Obtained Biosurfactant

Biosurfactant Recovery

Ten milliliters of an overnight culture of bacterial strains, in MRS broth, was added to $500 \mathrm{~mL}$ of MRS broth and incubated for 7 days at $35^{\circ} \mathrm{C}$. The bacteria were removed (10000 rpm for 15 minutes) to recover the biosurfactant. The $\mathrm{pH}$ of the supernatant was adjusted to 2 with $6 \mathrm{~N} \mathrm{HCl}$ and then the solution was stored at $4^{\circ} \mathrm{C}$ for 24 hours. The precipitated biosurfactants recovered using a combination of chloroform and methanol $(2: 1 \mathrm{v} / \mathrm{v})$ and mixed vigorously to obtain the biosurfactant within the organic layer. The biosurfactants move from the hydrophilic phase (MRS broth) into the organic, hydrophobic phase. This layer was separated using a separating funnel and dried at $50^{\circ} \mathrm{C}$ for $4-5$ hours to obtain dry mass and analyzed by FTIR spectroscopy. ${ }^{22}$

\section{Fourier-Transform Infrared Spectroscopy}

Four milligrams of partially purified biosurfactant was dried (applying a freeze dryer) and then grounded with $100 \mathrm{mg}$ of potassium bromide (KBr) and pressed to obtain translucent pellets. Then analyzed in an FTIR (Bruker: Tensor 27, Germany), device at the range of 400-4000 wavenumbers $\left(\mathrm{cm}^{-1}\right)$.

\section{Antibacterial Activity of Biosurfactant}

In vitro antibacterial activities of biosurfactants against Gram-positive (Staphylococcus aureus PTCC 1431 and Bacillus cereus PTCC 1015) and gram-negative bacteria (Salmonella entritidis PTCC 1709, Escherichia coli PTCC 1270 and Pseudomonas aeruginosa CZO Accession number: JX441328) were investigated by the agar disc diffusion method. The biosurfactants were dissolved in double-distilled water, sterilized by filtration and stored at $4^{\circ} \mathrm{C}$. The sets of four dilutions $(1000,500,250$ and $125 \mathrm{mg} / \mathrm{mL}$ ) of biosurfactants were prepared in doubledistilled water. Mueller-Hinton sterile agar (Himedia, India) plates were seeded with indicator bacterial strains $\left(10^{8} \mathrm{CFU} / \mathrm{mL}\right)$ and allowed to stay at $37^{\circ} \mathrm{C}$ for 3 hours. Control experiments were carried out under similar condition by using Ampicillin $(10 \mu \mathrm{g} / \mathrm{ml})$, Gentamicin (10 $\mu \mathrm{g} / \mathrm{mL})$, Amikacin $(30 \mu \mathrm{g} / \mathrm{mL})$, Amoxicillin $(25 \mu \mathrm{g} / \mathrm{mL})$ and ciprofloxacin $(5 \mu \mathrm{g} / \mathrm{mL}$; Padtan Teb, Tehran, Iran) for antibacterial activity as standard drugs. The zones of growth inhibition around the discs were measured after 18 to 24 at $37^{\circ} \mathrm{C}$.

\section{Results}

Separation and Characterization of Biosurfactant Generating Bacteria

The initial isolation yielded a total of 337 morphologically distinct microbial colonies. Among them, 63 isolates (54 gram-positive, catalase-negative cocci and 9 grampositive, catalase-negative bacilli) were isolated. Among the isolated bacteria, 25 isolates gave a positive response to hemolytic activity; of these 10 isolates showed positive oil spreading test (Figure 1) and 9 positive responses were obtained by the oil collapse method. Data presented in Table 1 exhibits the screening methods of biosurfactant producing bacteria. The positive isolates were further evaluated by the secondary assay; i.e. Emulsification activity test (Figure 2). Following complementary screening, three potential biosurfactant producing strains (HM-1, HM-2 and HM-3) were selected.

\section{Phylogenetic Analysis}

Phylogenetic affiliation of the screened strains was ascertained by $16 \mathrm{~S}$ rRNA gene sequence analysis. In order to find the most similar available sequences, a BLAST search was done in NCBI database. 16S rRNA gene sequence data of most closely related species were retrieved and used in tree construction to demonstrate the taxonomy of these isolates. Figure 3 shows the inferred phylogenetic relationships derived from a

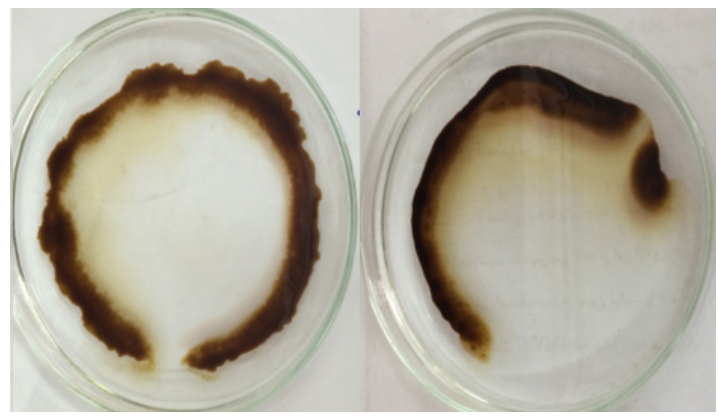

Figure 1. Oil Spreading Zone Exhibited by Isolated Strains.

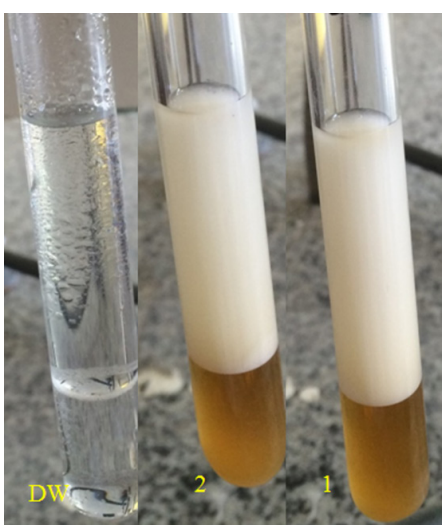

Figure 2. Emulsification Ability of Biosurfactant. 1: HM-1 strain, 2: HM-2 strain, 3: distilled water. 
Table 1. Detection of Biosurfactant Producing Isolates by Preliminary and Complementary Screening Methods

\begin{tabular}{|c|c|c|c|c|}
\hline \multirow{2}{*}{ Isolate } & \multicolumn{2}{|c|}{ Preliminary Methods } & \multicolumn{2}{|c|}{ Complementary Methods } \\
\hline & Hemolytic Activity & Oil Spreading & Oil Collapse & E24 \\
\hline $\mathrm{HM}-1$ & +++ & $65^{*}$ & +++ & $63.75 \pm 0.56$ \\
\hline $\mathrm{HM}-2$ & +++ & 77 & ++ & $62.33 \pm 0.23$ \\
\hline HM-3 & +++ & 75 & +++ & $21.11 \pm 0.25$ \\
\hline $\mathrm{HM}-4$ & +++ & 85 & +++ & $18.88 \pm 0.33$ \\
\hline $\mathrm{HM}-5$ & +++ & 64 & +++ & $18.05 \pm 0.23$ \\
\hline HM-6 & +++ & 64 & +++ & $13.75 \pm 0.3$ \\
\hline $\mathrm{HM}-7$ & +++ & 67 & +++ & $7.69 \pm 0.46$ \\
\hline HM-8 & +++ & 47 & +++ & $5.12 \pm 0.91$ \\
\hline HM-9 & +++ & 50 & +++ & $5.12 \pm .25$ \\
\hline HM-10 & +++ & 58.3 & +++ & $5 \pm 0.23$ \\
\hline HM-12 & +++ & 0 & - & $0 \pm 0$ \\
\hline HM-13 & +++ & 0 & - & $0 \pm 0$ \\
\hline HM-19 & +++ & 0 & - & $0 \pm 0$ \\
\hline HM-20 & +++ & 0 & - & $0 \pm 0$ \\
\hline HM-21 & +++ & 0 & - & $0 \pm 0$ \\
\hline $\mathrm{HM}-25$ & +++ & 0 & - & $0 \pm 0$ \\
\hline HM-28 & +++ & 0 & - & $0 \pm 0$ \\
\hline HM-30 & +++ & 0 & - & $0 \pm 0$ \\
\hline HM-31 & +++ & 0 & - & $0 \pm 0$ \\
\hline HM-35 & +++ & 0 & - & $0 \pm 0$ \\
\hline HM-39 & +++ & 0 & - & $0 \pm 0$ \\
\hline $\mathrm{HM}-43$ & +++ & 0 & - & $0 \pm 0$ \\
\hline HM-59 & +++ & 0 & - & $0 \pm 0$ \\
\hline HM-62 & +++ & 0 & - & $0 \pm 0$ \\
\hline HM-63 & +++ & 0 & - & $0 \pm 0$ \\
\hline Distilled water & - & 0 & - & $1.25 \pm 0.25$ \\
\hline
\end{tabular}

* Diameter of the clear zone in $\mathrm{mm}$.

neighbor-joining analysis of $16 \mathrm{~S}$ rRNA gene sequence of the $P$. pentosaceus HM-1, $P$. pentosaceus HM-2 and $P$. pentosaceus HM-3 with most validly described species of the genus Pediococcus.

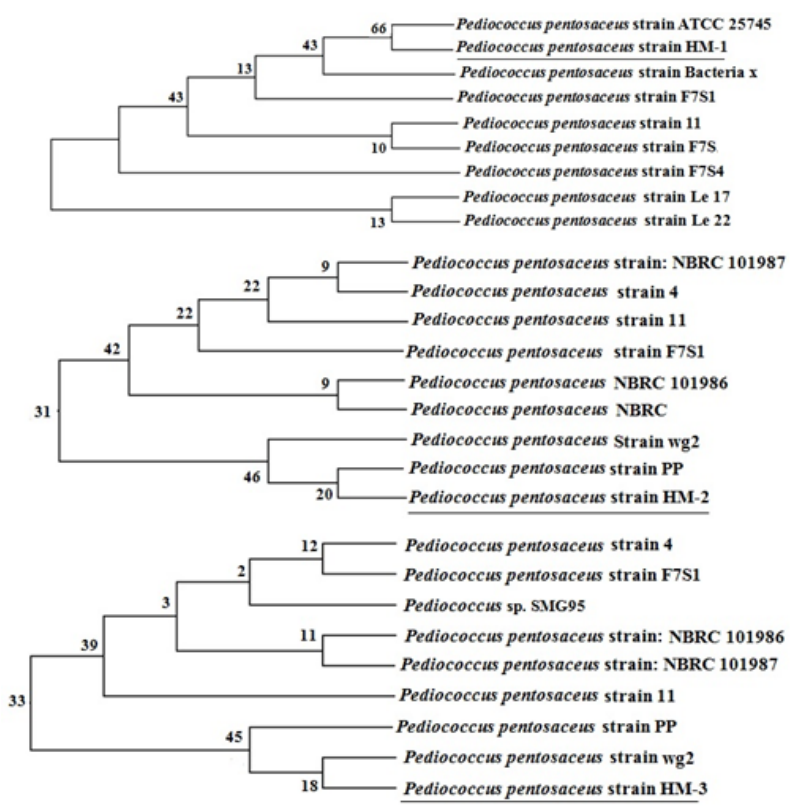

Figure 3. Neighbor-Joining Tree Based on $16 \mathrm{~S}$ rRNA Gene Sequences, Showing Relationships of Screened Strains With Closely Related Members of the Genus Pediococcus.
Antibacterial Activity of Biosurfactant

The results regarding the antibacterial activity of the different concentrations of biosurfactants are indicated in Table 2. Biosurfactants isolated from screened strains showed a wide activity against the indicator strains (Table 2 and Figure 4). The antibiotic sensitivity pattern analysis of indicator strains was tested against 5 different commonly used antibiotics and the results were presented in Table 3.

Fourier-Transform Infrared Spectroscopy

The Fourier-transform infrared spectroscopy (FTIR) spectrum is illustrated in Figure 5, which shows broad stretching peaks at $3442 \mathrm{~cm}^{-1}$ (as the indicator of $\mathrm{N}-\mathrm{H}$ stretching vibrations and strong hydrogen bonding). Absorption at 2997 and $2913 \mathrm{~cm}^{-1}$ are assigned to the symmetric stretch of $\mathrm{CH}_{2}$ and $\mathrm{CH}_{3}$ groups of aliphatic chains. The appearance of a weak absorbance signal at $2093 \mathrm{~cm}^{-1}$ may be due to $\mathrm{C}-\mathrm{N}$ stretch. The bands observed at $1659 \mathrm{~cm}^{-1}$ is a definite indicator of linkages between the amides I and II. The absorbance in this region is significant in the presence of the peptide group in the molecule. The band peaks at 1437, 1408 and $1312 \mathrm{~cm}^{-1}$, are characteristic of aliphatic chains' $\left(-\mathrm{CH}_{3},-\mathrm{CH}_{2}\right)$ bending vibrations. High-intensity peak in the region of $1047 \mathrm{~cm}^{-1}$ is assigned to $\mathrm{O}-\mathrm{C}-\mathrm{O}$ extend vibrations. The following vibrations observed at $500-1000 \mathrm{~cm}^{-1}$ are due to 
Table 2. Antibacterial Activity of the Different Concentrations of Biosurfactants Against Indicator Strains

\begin{tabular}{|c|c|c|c|c|c|}
\hline \multirow{2}{*}{ Strain } & \multirow{2}{*}{ Biosurfactant } & \multicolumn{4}{|c|}{ Inhibition Zone (mm) } \\
\hline & & $1000 \mathrm{mg} / \mathrm{mL}$ & $500 \mathrm{mg} / \mathrm{mL}$ & $250 \mathrm{mg} / \mathrm{mL}$ & $125 \mathrm{mg} / \mathrm{mL}$ \\
\hline \multirow{3}{*}{ E. coli } & BS-1 & $29 \pm 0.577$ & $16 \pm 0.288$ & $18 \pm 0.763$ & $11 \pm 0.5$ \\
\hline & BS-2 & $27 \pm 0.5$ & $18 \pm 0.288$ & $14 \pm 0.577$ & $8 \pm 0.763$ \\
\hline & BS-3 & $26 \pm 0.288$ & $19 \pm 0.5$ & $13 \pm 0.288$ & $7 \pm 0.5$ \\
\hline \multirow{3}{*}{ S. aureus } & BS -1 & $26 \pm 0.5$ & $20 \pm 0.288$ & $17 \pm 0.763$ & $12 \pm 0.288$ \\
\hline & BS-2 & $24 \pm 0.763$ & $23 \pm 0.288$ & $15 \pm 0.763$ & $10 \pm 0.5$ \\
\hline & BS-3 & $23 \pm 0.577$ & $19 \pm 0.288$ & $14 \pm 0.5$ & $11 \pm 0.288$ \\
\hline \multirow{3}{*}{ B. cereus } & BS-1 & $23 \pm 0.5$ & $10 \pm 0.763$ & $0 \pm 0$ & $0 \pm 0$ \\
\hline & BS-2 & $22 \pm 0.763$ & $14 \pm 0.763$ & $0 \pm 0$ & $0 \pm 0$ \\
\hline & BS-3 & $22 \pm 0.577$ & $16 \pm 0.5$ & $2 \pm 0.288$ & $0 \pm 0$ \\
\hline \multirow{3}{*}{ P. aeruginosa } & BS-1 & $24 \pm 0.288$ & $15 \pm 0.763$ & $14 \pm 0.288$ & $12 \pm 0.577$ \\
\hline & BS-2 & $23 \pm 0.288$ & $15 \pm 0.577$ & $14 \pm 0.5$ & $11 \pm 0.5$ \\
\hline & BS-3 & $22 \pm 0.5$ & $15 \pm 0.288$ & $13 \pm 0.288$ & $11 \pm 0.288$ \\
\hline \multirow{3}{*}{ S. entritidis } & BS-1 & $45 \pm 0.288$ & $42 \pm 0.288$ & $44 \pm 0.763$ & $40 \pm 0.288$ \\
\hline & BS-2 & $43 \pm 0.5$ & $43 \pm 0.5$ & $40 \pm 0.763$ & $38 \pm 0.288$ \\
\hline & BS-3 & $49 \pm 0.288$ & $45 \pm 0.288$ & $0.5 \pm 40$ & $35 \pm 0.5$ \\
\hline
\end{tabular}

BS1, BS-2, and BS-3: The isolated biosurfactants from HM-1, HM-2 and HM-3 strains.

Table 3. Antibacterial Activity of the Standard Drugs Against Indicator Bacterial Strains

\begin{tabular}{lcccc}
\hline Strain & \multicolumn{4}{c}{ Inhibition Zone (mm) } \\
\cline { 2 - 5 } & Gentamicin & Ampicillin & Amoxicillin & Amikacin \\
\hline E. coli & $18 \pm 0.288 \mathrm{~S}$ & $9 \pm 0.763 \mathrm{R}$ & $10 \pm 0.288 \mathrm{R}$ & $15 \pm 0.577 \mathrm{~S}$ \\
S. aureus & $17 \pm 0.577 \mathrm{~S}$ & $14 \pm 0.288 \mathrm{~S}$ & $20 \pm 0.577 \mathrm{~S}$ & $20 \pm 0.763 \mathrm{~S}$ \\
B. cereus & $17 \pm 0.763 \mathrm{~S}$ & $43 \pm 0.288 \mathrm{~S}$ & $40 \pm 0.288 \mathrm{~S}$ & $14 \pm 0.288 \mathrm{R}$ \\
P. aeruginosa & $21 \pm 0.763 \mathrm{~S}$ & $0 \pm 0 \mathrm{R}$ & $0 \pm 0 \mathrm{R}$ & $28 \pm 0.288 \mathrm{~S}$ \\
S. entritidis & $18 \pm 0.577 \mathrm{~S}$ & $14 \pm 0.5 \mathrm{I}$ & $18 \pm 0.5 \mathrm{~S}$ & $17 \pm 0.5 \mathrm{~S}$ \\
\hline
\end{tabular}

S: Susceptible, I: Intermediate, R: Resista.

out of plane $\mathrm{C}-\mathrm{H}$ bending.

\section{Discussion}

Human milk is a complex biological fluid adapted to fulfill the nutritional requirements of the rapidly growing infant. The characterization of the breast milk microorganisms contributes to addressing the biological role of milk microbiota in the maintenance of health of the newborn and lactating mother. ${ }^{2,3}$ The studies microbial features of human breast milk are restricted to those bacteria responsible for infancy infections. However, it is clear that the prevention of infant against pathogens is related to the natural flora of human milk. ${ }^{3}$ Although there is limited knowledge about the commensal or probiotic bacteria in breast milk, Staphylococci, Streptococci, Micrococci, Lactobacilli, and Enterococci constitute the majority., ${ }^{2,32}$ Biosurfactants are diverse groups of amphiphilic compounds with great diversity, environmental acceptability and a broad spectrum of functions and industrial applications.

The biosurfactant producing bacteria were checked using hemolytic activity, oil collapse and oil spreading tests. Selection of these methods was due to their strong advantages including simplicity, low cost, quick implementation and use of relatively common equipment that is accessible in almost every microbiological laboratory. ${ }^{11}$ The results of our experiments indicated,
$39.6 \%$ of total isolates were positive for hemolytic activity, $36 \%$ were positive for oil collapse and $40 \%$ were considered positive based on oil spreading and since these methods have shown differences, the isolates with more than one positive response were exposed to complementary screening including emulsion activity measurements. In the present study, three bacterial isolates ( $P$. pentosaceus

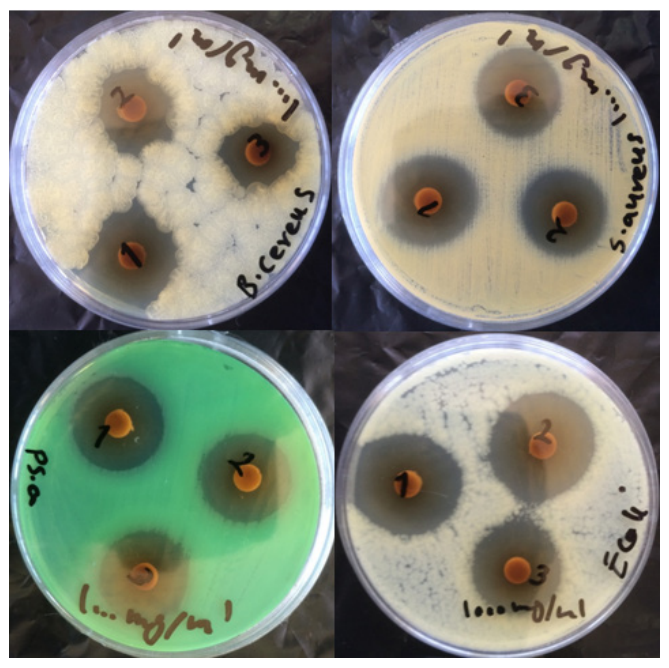

Figure 4. Antibacterial Activity of the Biosurfactants on the Growth of the Indicator Bacteria by Disc-Diffusion Method. 


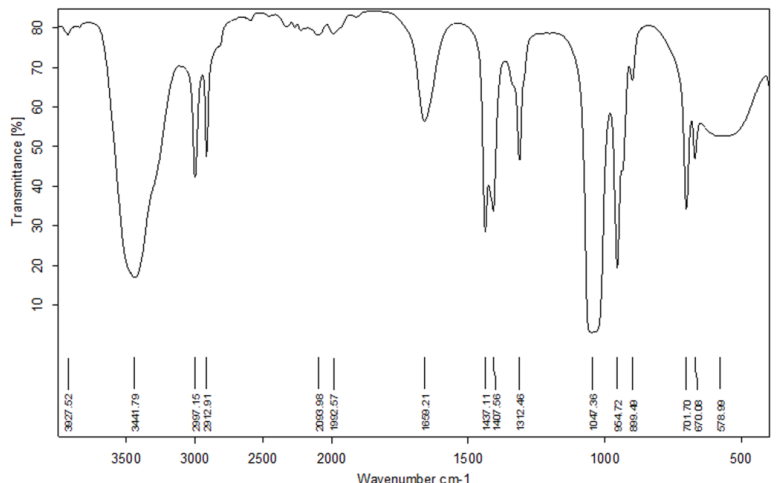

Figure 5. FTIR Spectra of the Biosurfactant Produced by HM-3 Strain

HM-1, P. pentosaceus HM-2 and P. pentosaceus HM-3) with biosurfactant-producing ability were isolated and screened from human milk samples. The biosurfactants derived from isolated strains showed significant antimicrobial activities against indicator bacteria at different concentrations. Baraka and Al-Rubayyi reported that the breast milk exerted bactericidal activity against E. coli, P. aeruginosa S. aureus and Salmonella sp. ${ }^{24}$ The antimicrobial activity results generated from our studies are in agreement with that reported by Ibhanesebhor and Otobo for inhibitory activities of human colostrum against $S$. aureus and coliform organisms. ${ }^{25}$

Our findings demonstrated that biosurfactants produced by screened strains, compared with synthetic antibiotics, had acceptable antimicrobial activity. Antimicrobial activity is one of the most important selection criteria for probiotics. Antimicrobial effects of prebiotic bacteria are formed by producing a variety of active biological compounds. ${ }^{26,27}$ For identifying types of functional groups in the unknown biosurfactants, FTIR analysis was used. The FTIR profile of the biosurfactant showed similarity to surfactin, a lipopeptide biosurfactant, and other lipopeptide biosurfactants like arthrofactin ${ }^{28}$ and lichenysin ${ }^{29}$ confirming the lipopeptide nature of the produced biosurfactant. According to Khopade et al, lipopeptide surfactants are potent antibiotics and had a wide antimicrobial activity. ${ }^{30}$

\section{Conclusion}

Biosurfactant producing probiotic bacteria could be safely isolated from human milk. These bacteria are necessary for improving intestinal microflora of infants. The antibacterial properties of the produced biosurfactant against bacterial strains suggest its potential use in the development of new pharmaceutical preparations.

\section{Ethical Approval}

Not applicable.

\section{Competing Interests}

None.

\section{Acknowledgments}

This research was supported by department of microbiology, Islamic Azad University, Kerman branch, Kerman, Iran.

\section{References}

1. Jara S, Sanchez M, Vera R, Cofre J, Castro E. The inhibitory activity of Lactobacillus spp. isolated from breast milk on gastrointestinal pathogenic bacteria of nosocomial origin. Anaerobe. 2011;17(6):474-477. doi:10.1016/j. anaerobe.2011.07.008

2. Martin R, Langa S, Reviriego C, et al. Human milk is a source of lactic acid bacteria for the infant gut. J Pediatr. 2003;143(6):754-758. doi:10.1016/j.jpeds.2003.09.028

3. Martin Ro, Langa S, Reviriego C, et al. The commensal microflora of human milk: new perspectives for food bacteriotherapy and probiotics. Trends in Food Science and Technology. 2004;15(3-4):121-127. doi:10.1016/j. tifs.2003.09.010

4. Albesharat R, Ehrmann MA, Korakli M, Yazaji S, Vogel RF. Phenotypic and genotypic analyses of lactic acid bacteria in local fermented food, breast milk and faeces of mothers and their babies. Syst Appl Microbiol. 2011;34(2):148-155. doi:10.1016/j.syapm.2010.12.001

5. Gueimonde M, Laitinen K, Salminen S, Isolauri E. Breast milk: a source of bifidobacteria for infant gut development and maturation? Neonatology. 2007;92(1):64-66. doi:10.1159/000100088

6. Perez-Cano FJ, Dong $\mathrm{H}$, Yaqoob P. In vitro immunomodulatory activity of Lactobacillus fermentum CECT5716 and Lactobacillus salivarius CECT5713: two probiotic strains isolated from human breast milk. Immunobiology. 2010;215(12):996-1004. doi:10.1016/j. imbio.2010.01.004

7. Rodrigues L, Banat IM, Teixeira J, Oliveira R. Biosurfactants: potential applications in medicine. J Antimicrob Chemother. 2006;57(4):609-618. doi:10.1093/ jac/dkl024

8. Singh P, Cameotra SS. Potential applications of microbial surfactants in biomedical sciences. Trends Biotechnol. 2004;22(3):142-146. doi:10.1016/j.tibtech.2004.01.010

9. Mukherjee S, Das P, Sen R. Towards commercial production of microbial surfactants. Trends Biotechnol. 2006;24(11):509-515. doi:10.1016/j.tibtech.2006.09.005

10. Van Hamme JD, Singh A, Ward OP. Physiological aspects. Part 1 in a series of papers devoted to surfactants in microbiology and biotechnology. Biotechnol Adv. 2006;24(6):604-620. doi:10.1016/j.biotechadv.2006.08.001

11. Youssef NH, Duncan KE, Nagle DP, Savage KN, Knapp RM, McInerney MJ. Comparison of methods to detect biosurfactant production by diverse microorganisms. J Microbiol Methods. 2004;56(3):339-347. doi:10.1016/j. mimet.2003.11.001

12. Tugrul T, Cansunar E. Detecting surfactant-producing microorganisms by the drop-collapse Test. World J Microbiol Biotechnol. 2005;21(6-7):851-853. doi:10.1007/ s11274-004-5958-y

13. Płaza GA, Zjawiony I, Banat IM. Use of different methods for detection of thermophilic biosurfactantproducing bacteria from hydrocarbon-contaminated 
and bioremediated soils. J Pet Sci Eng. 2006;50(1):71-77. doi:10.1016/j.petrol.2005.10.005

14. Tabatabaee A, Mazaheri Assadi M, Noohi AA, Sajadian VA. Isolation of biosurfactant producing bacteria from oil reservoirs. Iran J Environ Health Sci Eng. 2005;2(1):6-12.

15. Bodour AA, Guerrero-Barajas C, Jiorle BV, et al. Structure and characterization of flavolipids, a novel class of biosurfactants produced by Flavobacterium sp. strain MTN11. Appl Environ Microbiol. 2004;70(1):114-120.

16. Krepsky N, Da Silva FS, Fontana LF, Crapez MA. Alternative methodology for isolation of biosurfactantproducing bacteria. Braz J Biol. 2007;67(1):117-124.

17. Bergey DH, Holt JG. Bergey's Manual of Determinative Bacteriology. 9th ed. Baltimore, USA; Williams \& Wilkins; 1994.

18. Hall TA. BioEdit: a user-friendly biological sequence alignment editor and analysis program for Windows 95/98/NT. Nucleic Acids Symp Ser. 1999;41(2):95-98. doi:citeulike-article-id:691774

19. Altschul SF, Gish W, Miller W, Myers EW, Lipman DJ. Basic local alignment search tool. J Mol Biol. 1990;215(3):403410. doi:10.1016/s0022-2836(05)80360-2

20. Tamura K, Peterson D, Peterson N, Stecher G, Nei M, Kumar S. MEGA5: molecular evolutionary genetics analysis using maximum likelihood, evolutionary distance, and maximum parsimony methods. Mol Biol Evol. 2011;28(10):2731-2739. doi:10.1093/molbev/msr121

21. Felsenstein J. Confidence limits on phylogenies: an approach using the bootstrap. Evolution. 1985;39(4):783791. doi:10.1111/j.1558-5646.1985.tb00420.x

22. Desai JD, Banat IM. Microbial production of surfactants and their commercial potential. Microbiol Mol Biol Rev. 1997;61(1):47-64.

23. Heikkila MP, Saris PE. Inhibition of Staphylococcus aureus by the commensal bacteria of human milk. J Appl Microbiol. 2003;95(3):471-478.

24. Baraka AE, Al-Rubayyi KA. A comparative study on the antibacterial activity of camel and human milks. Egypt J Dairy Sci. 2012;40:7-14.

25. Ibhanesebhor SE, Otobo ES. In vitro activity of human milk against the causative organisms of ophthalmia neonatorum in Benin City, Nigeria. J Trop Pediatr. 1996;42(6):327-329.

26. Ouwehand AC, Kirjavainen PV, Shortt C, Salminen S. Probiotics: mechanisms and established effects. Int Dairy J. 1999;9(1):43-52. doi:10.1016/S0958-6946(99)00043-6

27. Bilkova A, Kinova Sepova H, Bukovsky M, Bezakova L. Antibacterial potential of lactobacilli isolated from a lamb. Vet Med. 2011;56(7):319-324. doi:10.17221/1583VETMED

28. Morikawa M, Daido H, Takao T, Murata S, Shimonishi Y, Imanaka T. A new lipopeptide biosurfactant produced by Arthrobacter sp. strain MIS38. J Bacteriol. 1993;175(20):6459-6466.

29. Lin SC, Minton MA, Sharma MM, Georgiou G. Structural and immunological characterization of a biosurfactant produced by Bacillus licheniformis JF-2. Appl Environ Microbiol. 1994;60(1):31-38.

30. Khopade A, Ren B, Liu XY, Mahadik K, Zhang L, Kokare C. Production and characterization of biosurfactant from marine Streptomyces species B3. J Colloid Interface Sci. 2012;367(1):311-318. doi:10.1016/j.jcis.2011.11.009 